\title{
Molecular dan Genomic Biomarker sebagai Deteksi Dini pada Diagnosis Kanker Prostat
}

\author{
Jihan Audini Karim \\ Pendidikan Dokter, Fakultas Kedokteran, Universitas Lampung \\ * e-mail: Jihanaudini1998@gmail.com
}

\begin{abstract}
Abstrak
Kanker prostat merupakan salah satu keganasan nonkutan pada pria, penyakit heterogen dengan hasil klinis bervariasi. Pendekatan klinis modern untuk kanker prostat menekankan perlunya penanganan untuk menghindari overdiagnosis dan overtreatment. Kemajuan dalam pemahaman tentang patogenesis kanker prostat, ditambah dengan inovasi teknologi, telah memfasilitasi pengembangan dan validasi sejumlah biomarker molekuler, mewakili berbagai makromolekul yang diuji dari berbagai jenis sampel pasien, untuk membantu manajemen klinis kanker prostat, termasuk deteksi dini, diagnosis, prognostikasi, dan pemilihan terapi yang ditargetkan. Kanker prostat tidak menunjukkan gejala pada tahap awal penyakit, terdapat beragam tanda klinis-patologis dan perkembangan penyakit, dan ditandai oleh sebagian besar oleh tipe kanker indolen. Oleh karena itu, sangat penting untuk mengembangkan pendekatan individual untuk deteksi dini, stratifikasi penyakit (indolent vs. aggressive) dan prediksi tanggapan pengobatan untuk kanker prostat. Artikel ini bersifat review artikel dimana peneliti meninjau keadaan terkini tentang penggunaan genomic biomarker sebagai deteksi dini kanker prostat, menunjukkan fungsi biomarker molekul dalam praktik klinis. Hasil dari artikel review ini bahwa tes genomik dan proteomik yang tersedia dapat meningkatkan nilai prediktif terhadap sistem klasifikasi risiko PCa berdasarkan pada variabel klinis
\end{abstract}

Kata Kunci: Biomarker, Molecular, Kanker, Prostat

\section{Molecular and Genomic Biomarker as Early Detection in Prostate Cancer Diagnosis}

\begin{abstract}
Prostate cancer is a noncutaneous malignancy in men, a heterogeneous disease with varying clinical outcomes. The modern clinical approach to prostate cancer emphasizes the need for treatment to avoid overdiagnosis and overtreatment. Advances in understanding of the pathogenesis of prostate cancer, coupled with technological innovations, have facilitated the development and validation of a number of molecular biomarkers, representing a variety of tested macromolecules from a wide variety of patient samples, to aid clinical management of prostate cancer, including early detection, diagnosis, prognostication, and selection. targeted therapy. Prostate cancer is asymptomatic in the early stages of the disease, there are various clinical-pathological signs and disease progression, and is characterized mostly by indolent cancer types. Therefore, it is imperative to develop individualized approaches for early detection, disease stratification (indolent vs. aggressive) and prediction of treatment response for prostate cancer. This article is a review article in which researchers review the current state of use of genomic biomarkers for early detection of prostate cancer, demonstrating the function of molecular biomarkers in clinical practice. The result of this review article is that the
\end{abstract}


Molecular dan Genomic Biomarker sebagai Deteksi Dini pada Diagnosis Kanker Prostat Jihan Audini Karim

available genomic and proteomic tests can increase the predictive value of the PCa risk classification system based on clinical variables.

Keywords: Biomarkers, Molecular, Cancer, Prostate

\section{PENDAHULUAN}

Kanker adalah penyebab kematian paling umum kedua di dunia modern. Diperkirakan dalam dua dekade jumlah kasus baru akan meningkat sekitar $70 \%$. Keganasan yang paling umum pada pria adalah kanker paru-paru, kanker prostat, kanker lambung, dan kanker kandung kemih. Kanker prostat (PCa) berkembang sebagai akibat dari proliferasi sel-sel prostat yang tidak terkendali. Pada 2015, 1,6 juta kasus baru didiagnosis di seluruh dunia, termasuk 1,1 juta di negara-negara maju. Sekitar 22,6\% dari kasus ini berakibat fatal (Feigin et al, 2017).

Meskipun kanker prostat bersifat umum pada laki - laki, perjalanan tumor yang tidak dipantau dengan baik dan pengobatan yang tidak tepat serta skrining dan deteksi dini kanker prostat yang tidak tepat dapat mengancam kesehatan jangka panjang dan tetap menjadi penyebab ketiga kematian akibat kanker pada pria (Barry and Hayes, 2015).

Skrining untuk semua jenis kanker bertujuan untuk meningkatkan peluang keberhasilan pengobatan melalui deteksi dini penyakit. Penggunaan biomarker dan teknik pencitraan canggih seperti multiparametrik dan pencitraan resonansi magnetik seluruh tubuh untuk mendeteksi $\mathrm{PCa}$ sedang sangat berkembang dalam beberapa tahun terakhir. Beberapa cara Diagnosis kanker prostat salah satunya didasarkan pada evaluasi mikroskopis dari jaringan prostat yang diperoleh melalui biopsi jarum. Dengan konvensi, biopsi prostat sistematis dilakukan dengan menggunakan USG transrektal untuk mendapatkan 10 hingga 12 sampel jaringan dalam pola seperti grid. Seorang ahli patologi memeriksa sampel menggunakan grade Gleason primer untuk pola histologis dominan dan grade sekunder untuk pola tertinggi, baik pada skala 1 hingga 5 berdasarkan tampilan mikroskopis dan penampilan sel. Dokter secara tradisional mengelompokkan diagnosis menjadi risiko rendah, menengah, dan tinggi berdasarkan jumlah pola Gleason, level antigen spesifik prostat (PSA), dan stadium klinis. Karena heterogenitas ada dalam setiap kelompok risiko, alat yang lebih spesifik telah dikembangkan dan divalidasi (Mohler et al, 2016). 
Penulisan Artikel review ini bertujuan untuk menganalisis molecular dan genomic biomarker yang dapat digunakan untuk deteksi dini terhadap kanker prostat dengan menyajikan beberapa biomarker yang telah dilakukan penelitian lebih lanjut dapat menjadi acuan diagnosis. Biomarker baru diperlukan untuk mengoptimalkan diagnosis PCa dengan lebih baik, yang akan membantu menghindari biopsi yang tidak tepat sekaligus meningkatkan kemungkinan biopsi positif

\section{PEMBAHASAN}

Kanker prostat ( $\mathrm{PCa}$ ) mengacu pada keganasan epitel yang terjadi pada prostat. Jenis patologis PCa termasuk adenokarsinoma (adenokarsinoma alveolar), adenokarsinoma duktus, karsinoma urothelial, karsinoma sel skuamosa, dan karsinoma adenoskuamosa. Tingkat kematian yang tinggi pada pasien PCa terutama disebabkan oleh fakta bahwa penyakit ini biasanya menjadi jelas secara klinis setelah metastasis. Tingkat kelangsungan hidup relatif berkisar 5 tahun, pada pasien dengan PCa lokal dan regional dapat mencapai $100 \%$, tetapi di antara pasien $\mathrm{PCa}$ metastasis, tingkat kelangsungan hidup 5 tahun jauh lebih rendah yaitu 30\% (Torre et al, 2015)
Kanker prostat dibagi menjadi beberapa kategori berdasarkan morfologi, misalnya, asinar adenokarsinoma dan pada stadium lanjut: $\mathrm{T}$ - kanker prostat awal yang hanya terletak di kelenjar prostat (subtipe TX, T0, T1a, T1b, T1c, T2a, T2b, T2c, T3a, T3b, T4); N - kanker lanjut lokal yang menempati kelenjar getah bening yang berdekatan (NX, NO, N1); $\mathrm{M}-$ metastasis (MX, M0, M1a, M1b, M1c) (Malinowsk et al, 2019). Tantangan dalam pengembangan biomarker kanker, termasuk kanker prostat, membutuhkan validasi luas dan validasi silang, perbandingan head to head dari biomarker potensial, pengembangan panel penanda yang berlaku untuk berbagai konteks dan terapi klinis, keterjangkauan, dan akses. Potensi biomarker harus memberikan informasi independen tambahan dari variabel klinis dan patologis yang telah mapan, untuk meningkatkan akurasi prediksi diagnosis, prognosis, dan respons pengobatan kanker prostat. Literatur dan langkah yang tersedia dan berkembang dalam penelitian biomarker kanker prostat, bersama dengan pengembangan platform superkomputer yang sangat terintegrasi, kemungkinan akan mengarah pada penemuan yang lebih menarik yang akan meningkatkan penilaian risiko individual dan manajemen klinis penyakit (Cazares et al, 2011). 
PCA3

PCA3 diukur dalam sampel urin yang dikumpulkan setelah pemeriksaan digital rectal examination (DRE) pada prostat agar sel dapat terkelupas dalam urin. DRE tiga stroke per lobus dilakukan dengan menerapkan tekanan kuat (permukaan ditekan sekitar $1 \mathrm{~cm}$ ) dari dasar ke puncak dan dari lateral ke garis median untuk setiap lobus. Tanpa DRE, tes PCA3 memberikan hasil yang valid hanya sekitar $80 \%$ dari kasus. Tes PCA3 membutuhkan pengumpulan 20-30 $\mathrm{mL}$ urin pertama setelah DRE. Sekitar $2 \mathrm{~mL}$ sampel urin ditempatkan ke dalam tabung transportasi dengan buffer lisis yang mengandung inhibitor ribonuklease (mRNA akan hancur dalam waktu 20 menit dengan tidak adanya inhibitor). Tabung transportasi dikirim semalam ke laboratorium khusus pada suhu kamar, tetapi juga dapat disimpan beku, sampel whole urine lebih sering digunakan. Tiga generasi berturutturut dari tes PCA3 telah dipresentasikan, mengarah ke kit yang tersedia secara komersial yang dikenal sebagai uji ProgensaTM PCA3 (Gen-Probe, San Diego, CA, USA)(Bourdoumis et al, 2010)

Pengujian PCA3 saat ini disetujui FDA untuk pria yang sebelumnya memiliki biopsi negatif dengan PSA yang terus meningkat untuk membantu mengidentifikasi pria yang membutuhkan biopsi ulang. PCA3 dikalibrasi untuk mengidentifikasi laki-laki berisiko rendah untuk biopsi positif sehingga PCA3 $<25$ menunjukkan bahwa aman untuk melupakan biopsi. Peningkatan skor berkorelasi langsung dengan kemungkinan biopsi berulang positif, dan prediksi hasil biopsi 4 tahun [94-96]. PCA3 kemudian telah dieksplorasi dan terbukti secara positif memprediksi deteksi kanker prostat pada biopsi awal dengan spesifisitas tinggi dan dapat membantu dalam pengambilan keputusan biopsi awal (Aubin et al, 2010).

\section{TMPRSS2: ERG}

Transkrip fusi gen transmembran protease serine 2 (TMPRSS2): $v$-ets erythroblastosis virus E26 oncogene homolog (ERG), juga disebut TMPRSS2: ERG atau T2E, telah diidentifikasi sebagai biomarker novel urin yang menjanjikan pada kanker prostat. sebagian besar tumor didorong oleh fusi gen ERG dengan TMPRSS2, yang keduanya terletak pada kromosom 21 (Wang et al, 2017). TMPRSS2 adalah gen androgen prostat yang mengkode protein milik serine protease, yang berfungsi dalam karsinogenesis prostat dan mengandalkan fusi gen dengan faktor transkripsi ETS, seperti ERG dan ETV1 (Yu et al, 2010). ERG adalah onkogen yang mengkodekan faktor transkripsi spesifik transformasi eritroblast (Tandefelt 
et al, 2014), yang merupakan pengatur utama proliferasi, diferensiasi, angiogenesis, peradangan, dan apoptosis sel. Penggabungan gen TMPRSS2: ERG adalah perubahan genomik yang paling sering terjadi pada kasus kanker prostat dan menghasilkan ekspresi berlebih dari faktor transkripsi ERG yang hadir pada kanker prostat tahap awal dan akhir (kanker prostat yang tahan kastrasi, CRPC) (Kissick et al, 2015). Penelitian yang dilakukan oleh Ding et al menemukan bahwa varian langka mungkin memiliki efek besar pada ekspresi gen yang mengakibatkan outlier ekspresi pada gen tersebut dalam subtipe penyakit. Uji-t konvensional dan ANOVA yang dilakukan tidak mendeteksi ekspresi langka yang tidak secara signifikan mengubah ekspresi rata-rata dalam suatu kelompok, digunakan metode Cancer Outlier Profile Analysis (COPA) untuk mendeteksi ekspresi gen asing. Ditemukan bahwa 79 dari 20261 gen menunjukkan ekspresi berlebih yang ditandai (outlier) dalam sampel tumor tertentu termasuk 3 gen kanker prostat yang dilaporkan sebelumnya (ERG, ETV1, dan SPINK1) (Ding et al, 2016).

Penelitian yang dilakukan oleh Kulda et al terhadap 108 pasien yang menjalani prostatektomi radikal. PSA diukur dalam darah perifer yang dikumpulkan sebelum operasi. Ekspresi transkrip TMPRSS2-ERG dan ekspresi miR-23b, miR-26a dan miR221 dalam jaringan tumor formalin-fix, parafinembedded (FFPE) dianalisis dengan transkripsi terbalik (RT) real-time polymerase chain reaction (PCR) menunujkan bahwa waktu rekurensi yang jauh lebih singkat diamati pada pasien dengan ekspresi tinggi TMPRSS2-ERG $(p=$ 0,0020). Penanda paling menjanjikan dari risiko kekambuhan setelah prostatektomi radikal adalah kombinasi dari level tinggi serum PSA pascaoperasi (Kulda et al, 2016)

\section{MicroRNAs}

Perbedaan ekspresi miRNA pada kanker prostat memiliki potensi untuk membedakan prognosis antara jinak dan ganas pada penyakit kanker prostat. Selain itu, miRNA memiliki kemampuan untuk mengidentifikasi penyakit indolen dan agresif, mendukung peran miRNA sebagai biomarker diagnostik dan prognostik pada kanker prostat (Kojima et al, 2017). Berbagai proses seluler dan jalur pensinyalan sel telah terlibat dalam kanker prostat yang peka terhadap kastrasi dan tahan kastrasi. Jalur seluler termasuk tetapi tidak terbatas pada perkembangan siklus sel, proliferasi sel, kematian sel, transisi epitel-mesenkimal (EMT), angiogenesis, metabolisme sel tumor dan metastasis.

Dalam penelitian yang dilakukan Matin et al terhadap 372 profil miRNA 
Molecular dan Genomic Biomarker sebagai Deteksi Dini pada Diagnosis Kanker Prostat Jihan Audini Karim

terkait kanker dalam plasma yang dikumpulkan sebelum ( 60\% pasien) dan setelah / selama dimulainya pengobatan ( $40 \%$ pasien), dari pasien kanker prostat yang cocok dengan usia dan kontrol sehat, dan mengamati peningkatan kadar 4 miRNAs - miR-4289, miR-326, miR-152-3p dan miR-98-5p, yang divalidasi dalam kohort independen. Panel miRNA mampu membedakan antara pasien kanker prostat dan kontrol ( $A \cup C=0,88$ ). Analisis data transkripsiomik miRNA yang dipublikasikan dari sampel klinis menunjukkan ekspresi miR-152-3p yang rendah pada tumor dibandingkan dengan jaringan non-ganas yang berdekatan. Overekspresi miR-152-3p meningkatkan proliferasi dan migrasi sel kanker prostat, menunjukkan peran miRNA dalam patogenesis kanker prostat, sebuah konsep yang didukung oleh analisis jalur prediksi gen target miR-152-3p yang diprediksi (Matin et al, 2018).

\section{CTCs}

Circulating tumor cells (CTCS) merupakan sekelompok sel kanker dari tumor primer atau bermetastasis ke dalam sirkulasi perifer, dianggap sebagai prekursor untuk metastasis neoplasma (M. $\mathrm{Yu}$ et al, 2011). Peran prediktif dan prognostik nomor CTC dalam pengaturan metastatic castration-resistant prostate cancer (mCRPC) telah distandarisasi dan divalidasi. Data dari beberapa uji klinis menunjukkan bahwa jumlah CTC pretreatment $\geq 5$ mungkin merupakan prediktor independen dari prognosis buruk dan terkait dengan kadar PSA yang lebih tinggi, anemia, penyakit hati, kadar alkali fosfatase yang lebih tinggi, dan gejala nyeri tulang pada pasien mCRPC (Goldkorn et al, 2014). Namun, CTC yang terdapat pada darah perifer telah lama terbukti menjadi tantangan utama, mengingat bahwa sangat jarang ditemui, dengan perkiraan jumlah satu CTC per $\mathrm{mL}$ darah (Hong \& Zu, 2013).

Semakin banyak platform teknologi telah dikembangkan untuk mendapatkan CTC dari sampel darah pasien kanker berdasarkan fitur fisik dan / atau biologis. Sampai saat ini, sistem CellSearch (Menarini-Silicon Biosystems, San Diego, CA, USA) adalah satu-satunya perangkat yang disetujui oleh Badan Pengawasan Obat dan Makanan (FDA) untuk enumerasi CTC dalam penggunaan klinis. Sistem ini memperkaya CTC dengan molekul adhesi sel epitel (EpCAM) yang dilapisi antibodi feromagnetik dan mengidentifikasi CTCS yang berasal dari epitel (CD45-, DAPI +, dan cytokeratin 8/18/19+) (Coumans et al, 2012). Untuk mengatasi kelimpahan CTC yang rendah, pendekatan pengayaan in vivo dilaporkan menggunakan CellCollector CANCER01 (DC01) (Saucedo-Zeni et al, 2012). Tidak seperti metode lain yang 
dibatasi oleh volume sampel darah, perangkat DC01 memungkinkan isolasi in vivo dan enumerasi CTC langsung dari aliran darah dengan menempatkan detektor melalui kanula ke dalam vena perifer pasien kanker, sehingga menangkap EpCAM- CTC positif.

Penelitian yang dilakukan oleh Chen et al pada CTC yang dianalisis dan dibandingkan sebelum dan sesudah radioterapi (dua titik waktu pengambilan sampel) pada 51 pasien PCa non metastatik berisiko tinggi dan selanjutnya dibandingkan menurut teknik isolasi; lebih lanjut, jumlah CTC berkorelasi dengan fitur klinis. Penggunaan DC01 menghasilkan persentase sampel CTC-positif yang secara signifikan lebih tinggi dibandingkan dengan CellSearch $(33,7 \%$ vs $18,6 \% ; p=0,024)$ dan menghasilkan angka CTC yang secara signifikan lebih tinggi (kisaran: $0-15$ vs $0-5$; $p=0,006)$. Analisis pasangan sampel yang cocok antara dua titik waktu pengambilan sampel menunjukkan tidak ada perbedaan dalam jumlah CTC yang ditentukan oleh kedua teknik. Jumlah CTC tidak berkorelasi dengan fitur klinis. Pengayaan in vivo menggunakan DC01 memiliki potensi untuk mendeteksi CTC pada efisiensi yang lebih tinggi dibandingkan dengan CellSearch, menunjukkan bahwa CTC adalah biomarker yang cocok dalam PCa non-metastatik berisiko tinggi (Chen et al, 2019).

\section{ANDROGEN RECEPTOR}

Androgen receptor (AR) adalah faktor transkripsi reseptor steroid untuk testosteron dan dihidrotestosteron yang terdiri dari empat domain utama, domain $\mathrm{N}$-terminal, domain pengikatan DNA, daerah engsel, dan domain pengikatan ligan. AR memainkan peran penting dalam kanker prostat, terutama castrationresistant prostate cancer (CRPC)(Steinestel et al, 2019). Bi-directional Sanger sequencing untuk gen Androgen Receptor dilakukan menggunakan PCR primers. Dari 1.029 mutasi yang ditemukan pada gen yang mengkode AR, 159 mutasi mempengaruhi laki-laki untuk terkena kanker prostat (Gottlieb et al, 2012). Selain itu, penelitian sebelumnya telah menunjukkan bahwa lamanya pengulangan di N-terminal domain mempengaruhi risiko kanker prostat pada pria (Schleutker, 2012). Sebuah meta-analisis dari 19 penelitian termasuk subjek Kaukasia, Afrika-Amerika dan Asia memperkirakan peningkatan risiko kanker prostat pada pria dengan pengulangan CAG yang lebih pendek ( $\leq 21)$. Namun, sebuah penelitian di Swedia menunjukkan bahwa pria dengan panjang AR CAG yang lebih pendek (misalnya, $\leq 22$ kali berulang) berisiko lebih besar terkena kanker prostat. Penelitian lain tidak menemukan hubungan antara durasi pengulangan AR CAG dan risiko 
Molecular dan Genomic Biomarker sebagai Deteksi Dini pada Diagnosis Kanker Prostat Jihan Audini Karim

kanker prostat (Yoo et al, 2014). Meskipun

bukti bahwa mutasi pada AR mempengaruhi laki-laki terhadap kanker prostat tidak diragukan lagi, AR NTD CAG yang berulang berhubungan dengan risiko kanker prostat tetap kontroversial.

Terapi Androgen deprivation dapat menekan kanker prostat yang hormonenaïve tetapi kanker prostat mengubah $A R$ dan beradaptasi untuk bertahan hidup di bawah tingkat androgen yang dikastrasi. Mekanisme ini termasuk mutasi titik AR, ekspresi berlebih AR, perubahan biosintesis androgen, varian splice AR aktif secara konstitutif tanpa pengikatan ligan, dan perubahan kofaktor androgen. Studi AR di CRPC mengungkapkan bahwa AR masih aktif di CRPC, dan tetap sebagai target potensial untuk mengobati CRPC (Fujita \& Nonomura, 2019).

Faktor transkripsi AR adalah pendorong utama pengembangan CRPC dan resistensi yang didapat terhadap obat yang diberikan untuk pengobatan CRPC, seperti abiraterone dan enzalutamide (Schrader et al, 2014), sementara sebagian kecil pasien memiliki CRPC yang tidak digerakkan oleh AR. Mekanisme molekuler di balik reaktivasi AR dalam CRPC meliputi amplifikasi dan ekspresi berlebih gen AR, mutasi $A R$, dan ekspresi varian $A R$ aktif konstitutif (AR-Vs) (Karantanos et al, 2015).

\section{PTEN}

PTEN bertindak sebagai dualspesifisitas fosfatase, mengubah phosphatidylinositol 3,4,5-trisphosphate (PI $\quad(3,4,5) \quad \mathrm{P}_{3}$ atau $\left.\mathrm{PIP}_{3}\right)$ menjadi phosphatidylinositol 4,5-bifosfat (PI $(4,5) \mathrm{P}_{2}$ atau $\mathrm{PIP}_{2}$ ). Dengan cara ini, PTEN berfungsi sebagai antagonis langsung dari aktivitas kelas I PI3K, sekumpulan enzim yang mengubah PIP2 menjadi PIP3, menghasilkan aktivasi RAC- $\alpha$ serin/ threonine-protein kinase (AKT) hilir dan target mekanis dari kaskade pensinyalan rapamycin (mTOR) (Song et al, 2012).

Dengan meningkatnya jumlah pasien yang menunda terapi definitif untuk kanker prostat, terdapat kebutuhan yang tidak terpenuhi akan biomarker molekuler yang membantu membedakan tumor prostat yang jinak dan yang ganas. Karena kehilangan PTEN biasanya hadir dan subklonal pada tumor prostat primer. Metodologi in situ untuk deteksi kehilangan PTEN mungkin lebih disukai daripada metode yang menilai variasi nomor salinan berdasarkan ekstraksi asam nukleat, seperti sekuensing. Immunohistochemistry (IHC) dan fluorescence in situ hybridization (FISH) telah digunakan untuk menilai hilangnya PTEN pada jaringan formalin fixed paraffin embedded (FFPE) dilakukan dengan jaringan biopsi diagnostik untuk 
ISSN 1978-2071 (Print); ISSN 2580-5967 (Online) Jurnal IImiah Kedokteran Wijaya Kusuma 9(2) : 156-169, September 2020

pewarnaan imunohistokimia (IHC) (Lotan et al, 2011).

Kehilangan fungsi fosfatase dan tensin homolog (PTEN) mengarah ke aktivasi jalur PI3K-AKT (phosphoinositide 3kinase-RAC-alpha serine / treonine-protein kinase) dan sangat terkait dengan hasil onkologis yang merugikan, menjadikan PTEN sebagai genomik yang berpotensi bermanfaat untuk membedakan indolen dari penyakit agresif pada pasien dengan tumor yang terlokalisasi secara klinis. Di sisi lain dari spektrum penyakit, senyawa terapi yang menargetkan node pada jalur pensinyalan PI3K- AKT-mTOR (target mekanis rapamycin) sedang diuji dalam uji klinis untuk pasien dengan kanker prostat yang resisten terhadap kastrasi metastasis. Pengetahuan tentang status PTEN mungkin membantu untuk mengidentifikasi pasien yang lebih mungkin mendapat manfaat dari terapi ini. Untuk memungkinkan penggunaan status PTEN sebagai biomarker prognostik dan prediktif, tes yang telah divalidasi secara analitis telah dikembangkan untuk deteksi yang andal dan dapat direproduksi dari kehilangan PTEN dalam jaringan tumor dan biopsi cairan darah. Penggunaan uji kadar klinis dalam jaringan tumor telah menunjukkan korelasi yang kuat antara kehilangan PTEN dan proteinnya serta hubungan yang kuat antara kehilangan PTEN dan gambaran patologis yang merugikan serta hasil onkologis. Pada penyakit lanjut, menilai status PTEN dalam biopsi cair menunjukkan harapan dalam memprediksi respons terhadap terapi yang ditargetkan. Akhirnya, penelitian telah menunjukkan bahwa PTEN mungkin memiliki fungsi tambahan yang independen dari jalur PI3KAKT, termasuk yang mempengaruhi pertumbuhan tumor melalui modulasi respon imun dan lingkungan mikro tumor (Jamaspishvili et al, 2018).

Tabel 1. Nama test beserta analisa

\begin{tabular}{|l|c|c|}
\hline \multicolumn{1}{|c|}{ Biomarker } & Nama Test & Analisa \\
\hline PCA3 & PCA3 TEST & $\begin{array}{c}\text { Prediksi positive ditunjukan dengan skor PCA3> } \\
\text { 35 (Barbera } \text { et al, 2012) }\end{array}$ \\
\hline TMPRSS2: ERG & $\begin{array}{c}\text { Cancer Outlier Profile } \\
\text { Analysis (copa) }\end{array}$ & $\begin{array}{c}\text { Prediksi positive terlihat jika terdapat alterasi dan } \\
\text { fusi gen (Wang et al, 2017) }\end{array}$ \\
\hline MicroRNAs & $\begin{array}{c}\text { Quantitative Real-Time PCR } \\
\text { (RT-qPCR) }\end{array}$ & $\begin{array}{c}\text { Prediksi positive jika jumlahnya meningkat (angka } \\
\text { pasti masih dalam penelitian lebih lanjut) (Bidarra } \\
\text { et al, 2019) }\end{array}$ \\
\hline CTCs & CTC Test & CTC pretreatment $\geq 5$ (Goldkorn et al, 2014) \\
\hline Androgen Receptor & PCR Primer & Mutasi pada AR NTD CAG (Yoo et al, 2014) \\
\hline PTEN & Pewarnaan imunohistokimia & Delesi atau mutase (Jamaspishvili et al, 2018) \\
\hline
\end{tabular}


Terdapat revolusi dalam biomarker molekuler yang tersedia untuk deteksi dini, diagnosis, dan pengobatan kanker prostat. Mengingat fokus baru pada pengeluaran dan kemanjuran dalam semua aspek sistem perawatan kesehatan modern, namun, di tahun-tahun mendatang pasti akan ada peningkatan tekanan untuk membenarkan manfaat klinis dari uji molekuler yang mahal, terutama yang mengevaluasi hanya satu atau sekelompok kecil biomarker. Dengan pemikiran tersebut, kemajuan teknologi baru-baru ini telah mendorong pengembangan tes biomarker molekuler komprehensif yang menilai ratusan atau ribuan biomarker secara bersamaan. Sebagai contoh, teknologi sekuensing generasi berikutnya (next generation) telah memfasilitasi pengembangan tes sekuensing DNA dan RNA yang ditargetkan multipleks. Teknologi ini secara bersamaan dapat menilai varian somatik, perubahan jumlah salinan, dan ekspresi gen dari sampel jaringan klinis rutin yang kecil, seperti biopsi inti prostat dan jaringan metastasis menit yang lebih kecil.

\section{KESIMPULAN}

Tes genomik dan proteomik yang tersedia yang dijelaskan sebelumnya dapat meningkatkan nilai prediktif terhadap sistem klasifikasi risiko PCa berdasarkan pada variabel klinis. Namun demikian, penelitian lebih lanjut diperlukan untuk memvalidasi tes ini untuk membantu dalam keputusan perawatan yang disesuaikan

\section{DAFTAR PUSTAKA}

Aubin MJ, Reid J, Sarno MJ, Blasé A., Aussie $\mathrm{J}$ et al. PCA3 molecular urine test for predicting repeat prostate biopsy outcome in populations at risk: Validation in the placebo arm of the dutasteride REDUCE trial. Journal of Urology. 184(5): 19471952.

Barbera M, Pepe P, Paola Q, \& Aragona F, 2012. PCA3 score accuracy in diagnosing prostate cancer at repeat biopsy: Our experience in 177 patients. Archivio Italiano Di Urologia e Andrologia. 84(4): 227229.

Barry MJ and Hayes JH, 2015. Evaluating an elevated screening PSA Test. Journal of the American Medical Association. 314(19): 2073-2074.

Bidarra D, Constâncio V, Barros-Silva D, Ramalho-Carvalho J, MoreiraBarbosa C, et al, 2019. Circulating MicroRNAs as Biomarkers for Prostate Cancer Detection and Metastasis Development 
Prediction. Frontiers in Oncology.

9: 1-8.

Bourdoumis A, Papatsoris AG, Chrisofos M, Efstathiou E, Skolarikos A, et al, 2010. The novel prostate cancer antigen 3 (PCA3) biomarker. International Braz J Urol. 36(6): 665-668.

Cazares LH, Drake RR, Esquela-Kirscher A, Lance RS, Semmes OJ et al, 2011. Molecular pathology of prostate cancer. Cancer Biomarkers. 9(1-6): 441-459.

Chen S, Tauber G, Langsenlehner T, Schmölzer LM, Pötscher $M$, et al, 2019. In Vivo detection of circulating tumor cells in High-Risk Non-Metastatic Prostate Cancer Patients undergoing Radiotherapy. Cancers (Basel). 11(7): 933.

Coumans FAW, Ligthart ST, Uhr JW \& Terstappen LWMM, 2012. Challenges in the enumeration and phenotyping of CTC. Clinical Cancer Research. 18(20): 57115718.

Ding Y, Wu H, Warden C, Steele L, Liu X, et al, 2016. Gene Expression Differences in Prostate Cancers between Young and Old Men. PLoS Genetics. 12(12): e1006477. Feigin VL, Krishnamurthi RV, Theadom AM,
Abajobir AA, Mishra SR, et al, 2017. Global, regional, and national burden of neurological disorders during 1990-2015: a systematic analysis for the Global Burden of Disease Study 2015. The Lancet Neurology. 16(11): 877-897.

Fujita K, and Nonomura N, 2019. Role of Androgen Receptor in Prostate Cancer: A Review. The World Journal of Men's Health. 37(3): 288-295.

Goldkorn A, Ely B, Quinn DI, Tangen CM, Fink LM, et al, 2014. Circulating tumor cell counts are prognostic of overall survival in SWOG S0421: A phase III trial of docetaxel with or without atrasentan for metastatic castration-resistant prostate cancer. Journal of Clinical Oncology. 32(11): 1136-1142.

Gottlieb B, Beitel LK, Nadarajah A, Paliouras M, and Trifiro M, 2012. The Androgen Receptor Gene Mutations Database: 2012 Update. Human Mutation. 33(5): 887-894.

Hong B, and $\mathrm{Zu}$ Y, 2013. Detecting circulating tumor cells: Current challenges and new trends. Theranostics. 3(6): 377-394.

Jamaspishvili T, Berman DM, Ross AE, 
Molecular dan Genomic Biomarker sebagai Deteksi Dini pada Diagnosis Kanker Prostat Jihan Audini Karim

Scher HI, De Marzo AM, et al, 2018. Clinical Implications of PTEN Loss in Prostate Cancer. Nature Reviews Urology. 15(4): 222-234.

Karantanos T, Evans CP, Tombal B, Thompson TC, Montironi R, et al, 2015. Understanding The Mechanisms of Androgen Deprivation Resistance in Prostate Cancer at The Molecular Level. European Urology. 67(3): 470-479. Kissick HT, On ST, Dunn LK, Sanda MG, Asara JM, et al, 2015. The Transcription Factor ERG Increases Expression of Neurotransmitter Receptors on Prostate Cancer Cells. BMC Cancer. 15: 604.

Kojima S, Goto Y, and Naya Y, 2017. The Roles of Micrornas in the Progression of CastrationResistant Prostate Cancer. Journal of Human Genetics. 62: 25-31.

Kulda V, Topolcan O, Kucera R, Kripnerova M, Srbecka K, et al, 2016. Prognostic Significance of Tmprss2-Erg Fusion Gene in Prostate Cancer. Anticancer Research. 36(9): 4787-4793.

Lotan TL, Gurel B, Sutcliffe S, Esopi D, Liu W, et al, 2011. PTEN Protein Loss By Immunostaining: Analytic Validation and Prognostic
Indicator for A High Risk Surgical Cohort of Prostate Cancer Patients. Clinical Cancer Research. 17(20): 6563-6573.

Malinowski B, Wiciński M, Musiała N, Osowska I, and Szostak M, 2019. Previous, Current, and Future Pharmacotherapy and Diagnosis of Prostate Cancer-A Comprehensive Review. Diagnostics (Basel). 9(4): 161.

Matin F, Jeet V, Moya L, Selth LA, Chambers S, et al, 2018. A Plasma Biomarker Panel of Four MicroRNAs for The Diagnosis of Prostate Cancer. Scientific Reports. 8: 6653.

Mohler JL, Armstrong AJ, Bahnson RR, D’Amico AV, Davis BJ, et al, 2016. Prostate Cancer, Version 1.2016. Journal of the National Comprehensive Cancer Network. 14(1): 19-30.

Saucedo-Zeni N, Mewes S, Niestroj R, Gasiorowski L, Murawa D, et al, 2012. A Novel Method for the in Vivo Isolation of Circulating Tumor Cells from Peripheral Blood Of Cancer Patients Using a Functionalized and Structured Medical Wire. International Journal of Oncology. 41(4): 12411250. 
Schleutker J, 2012. Polymorphisms in

R143-152.

Androgen Signaling Pathway

Predisposing to Prostate Cancer.

Molecular and Cellularssss

Endocrinology. 360(1-2): 25-37.

Schrader AJ, Boegemann M, OhImann CH,

Torre LA, Bray F, Siegel RL, Ferlay J, LortetTieulent J, et al, 2015. Global cancer statistics, 2012. CA: A Cancer Journal for Clinicians. 65(2): 87-108.

Schnoeller TJ, Krabbe L, et al, 2014. Enzalutamide in CastrationResistant Prostate Cancer Patients Progressing after Docetaxel and Abiraterone. European Urology. 65(1): 30-36.

Wang Z, Wang Y, Zhang J, Hu Q, Zhi F, et al, 2017. Significance of the TMPRSS2: ERG Gene Fusion in Prostate Cancer. Molecular Medicine Reports. 16(4): 54505458.

Song MS, Salmena L, and Pandolfi PP, 2012. The Functions and Regulation of The PTEN Tumour Suppressor. Nature Reviews Molecular Cell Biology. 13: 283296.

Steinestel J, Luedeke $M$, Arndt A, Schnoeller TJ, Lennerz JK, et al, 2019. Detecting Predictive Androgen Receptor Modifications in Circulating Prostate Cancer Cells. Oncotarget. 10(41): 42134223.

Tandefelt DG, Boormans J, Hermans K, and Yoo S, Pettersson A, Jordahl KM, Lis RT,
Lindstrom S, et al, 2014.
Androgen Receptor CAG Repeat
Polymorphism and Risk of
TMPRSS2: ERG-Positive Prostate
Cancer. Cancer Epidemiology
Biomarkers and Prevention.
23(10): 2027-2031. Yu J, Yu J, Mani RS, Cao Q, Brenner CJ, et al, 2010. An Integrated Network of Androgen Receptor, Polycomb, and TMPRSS2-ERG Gene Fusions in Prostate Cancer Progression. Cancer Cell. 17(5): 443-454.

Trapman J, 2014. ETS Fusion Genes in Prostate Cancer. Endocrine-Related Cancer. 21(3): 
Molecular dan Genomic Biomarker sebagai Deteksi Dini pada Diagnosis Kanker Prostat Jihan Audini Karim

Yu M, Stott S, Toner M, Maheswaran S, and

Haber DA, 2011. Circulating

Tumor Cells: Approaches to

Isolation and Characterization.

Journal of Cell Biology. 192(3):

373-382. 